\title{
Integrasi Metode Pembelajaran Talking Stick dan Metode Pembelajaran Tebak Kata di Kelas VIII pada Mata Pelajaran IPS di SMP Negeri 4 Sepauk
}

\author{
Fatkhan Amirul Huda ${ }^{1)^{*}}$, Munawar Thoharudin ${ }^{1)}$ \\ ${ }^{1)}$ STKIP Persada Khatulistiwa Sintang \\ *fatkhanamirulhuda@gmail.com
}

Informasi Artikel

Tanggal Publikasi

23 Desember 2021

\section{Kata Kunci}

Metode Talking Stick

Metode Tebak Kata

Hasil Belajar

\begin{abstract}
Abstrak
Tujuan penelitian ini adalah untuk meningkatkan hasil belajar siswa melalui integrasi metode talking stick dan metode tebak kata pada siswa kelas VIII SMP Negeri 4 sepauk. Berdasarkan observasi didapatkan masih rendahnya nilai hasil belajar siswa kelas VIII pada mata pelajaran IPS yang lebih rendah dari KKM yaitu 70. Aktivitas belajar siswa pada siklus I diperoleh rata-rata sebesar $65 \%$ dengan kriteria baik. Pada siklus II hasil aktivitas belajar siswa diperoleh rata-rata sebesar 90\% dengan kriteria sangat baik. Peningkatan hasil belajar siswa pada siklus I dengan nilai rata-rata $72,22 \%$ dan meningkat di siklus II dengan nilai rata-rata sebesar 82,83\%. Sehingga terjadi peningkatan hasil belajar sebesar 10,61\%. Ketuntasan belajar klasikal siswa pada siklus I sebesar $60,86 \%$ dengan 14 orang tuntas dan 9 orang tidak tuntas. Pada siklus II ketuntasan belajar klasikal mencapai 91,3\% dengan jumlah siswa yang tuntas 21 orang dan 2 orang tidak tuntas. Peningkatan ketuntasan klasikal siswa adalah sebesar 30,43\%. Berdasarkan penelitian yang dilakukan, dapat disimpulkan bahwa melalui integrasi metode talking stick dan metode tebak kata dapat meningkatkan hasil belajar siswa pada mata pelajaran IPS tema pengaruh Interaksi sosial terhadap kehidupan sosial dan kebangsaan di kelas VIII di SMP Negeri 4 Sepauk.
\end{abstract}

This is an open access article under the CC - BY license

\section{PENDAHULUAN}

Belajar adalah proses interaksi terhadap semua situasi yang ada di sekitar individu. Belajar adalah proses yang diarahkan kepada tujuan dan proses berbuat melalui berbagai pengalaman. Belajar juga merupakan proses melihat, mengamati, dan memahami sesuatu. Belajar bukanlah sesuatu yang terjadi secara alamiah, tetapi hanya akan terjadi dengan adanya kondisi-kondisi tertentu, yaitu kondisi internal, yang menyangkut kesiapan siswa dan apa yang telah dipelajari sebelumnya, dan eksternal, yang merupakan situasi belajar dan penyajian stimuli yang secara sengaja diatur oleh guru dengan tujuan memperlancar proses belajar (Gagne, 1989, p. 114).

Proses pembelajaran yang dilakukan di sekolah terlihat monoton. Terlihat dari hasil wawancara yang dilakukan dengan guru mata pelajaran ternyata guru lebih sering menggunakan metode ceramah, menghafal, dan memberikan tugas. Kurangnya metode pembelajaraan yang diberikan oleh guru mengakibatkan rendahnya hasil belajar siswa terutama untuk mata pelajaran IPS pada tema pengaruh Interaksi sosial terhadap kehidupan sosial dan kebangsaan. Ditemukan bahwa siswa kelas VIII memiliki nilai ulangan harian pada mata pelajaran IPS yang rendah dari KKM yaitu $70 \mathrm{Hal}$ ini dibuktikan dengan nilai ulangan harian pada mata pelajaran IPS yang rendah yaitu dari 24 siswa yang tuntas hanya 6 orang 
jika dipersentasikan jumlahnya hanya 25\% sedangkan yang tidak tuntas jumlahnya sebanyak 18 orang jika dipresentasikan yaitu $75 \%$.

Tujuan dari ilmu pendidikan sosial (IPS) adalah untuk medidik dan memberi bekal kemampuan dasar kepada orang lain sesuai bakat, minat, kemampuan, dan lingkungannya, serta sebagai bekal untuk melanjutkan pendidikan kejenjangan yang lebih tinggi. Kegiatan belajar mengajar harus memberikan bukti secara nyata yang menunjukan keberhasilan siswa dalam mengajar. Mengetahui kemampuan dan keberhasilan siswa adalah cara yang paling tepat untuk meningkatkan hasil belajar siswa. Untuk itu penggunaan metode pembelajaran harus mampu menjadikan siswa menjadi lebih aktif agar terjadi perubahan pada siswa dalam proses pembelajaran, metode pembelajaran harus di pilih dan dirancang dengan baik agar kegiatan pembelajaran dapat mencapai hasil yang maksimal. Pembelajaran adalah suatu sistem, terdiri dari komponen yang saling berhubungan satu dengan yang lain. Komponen tersebut meliputi: tujuan, materi, metode, dan evaluasi. Keempat komponen pembelajaran tersebut harus diperhatikan oleh guru dalam memilih dan menentukan pendekatan, dan metode-metode pembelajaran apa yang akan digunakan dalam kegiatan pembelajaran. Menurut (Kurniasih \& Sani, 2016, p. 82) mengemukakan bahwa metode talking stick (tongkat berbicara) merupakan metode pembelajaran kelompok dengan bantuan tongkat. Metode talking stick adalah model pembelajaran kooperatif. Metode pembelajaran ini dilakukan dengan bantuan tongkat. Tongkat dijadikan sebagai alat giliran untuk berpendapat serta menjawab pertanyaan dari guru setelah siswa mendapatkan dan mempelajari materi yang di berikan oleh guru.

Menggunakan metode pembelajaran bukan sekedar upaya untuk membantu guru dalam mengajar, tetapi juga sebagai usaha untuk memudahkan siswa dalam mempelajari dan memahami materi pembelajaran. Seperti penelitian (Putri et al., 2016) dengan penelitian berjudul, "Peningkatan Kemampuan Berbicara Dengan Menggunakan Metode Talking Stick Pada Siswa Kelas VIII 6 Sekolah Menengah Pertama Negeri 4 Denpasar dan penelitian (Windari, Suniti, 2017) dengan judul "Penerapan Model Cooperative Learning Tipe Tebak Kata Dalam Meningkatkan Keaktifan Dan Hasil Belajar Siswa Pada Mata Pelajaran Ilmu Pengetahuan Sosial Kelas VII-B Di Madrasah Tsanawiyah Negeri 1 Losari Kabupaten Cirebon Dapat Meningkatkan Hasil Belajar Siswa”.

Berdasarkan latar belakang masalah di atas, dari masalah yang ada banyak solusi yang ditawarkan melalui metode pembelajaran yang akan digunakan oleh guru untuk mengajar. Penulis menawarkan sebuah solusi yaitu melalui metode pembelajaran yang dapat meningkatkan hasil belajar dalam pembelajaran. Salah satunya ialah dengan menggunakan integrasi metode pembelajaran Talking Stick dan metode pembelajaran tebak kata yaitu agar siswa berminat, aktif, dan tertarik untuk mengikuti proses pembelajaran serta melibatkan siswa secara langsung dalam proses belajar.

Tujuan dari penelitian ini untuk mengetahui apakah integrasi dari metode pembelajaran talking stick dan metode pembelajaran tebak kata dapat meningkatkan hasil belajar mata pelajaran IPS siswa SMP Negeri 4 Sepauk pada tema pengaruh interaksi sosial terhadap kehidupan sosial dan kebangsaan.

\section{METODE PENELITIAN}

Penelitian ini menggunakan pendekatan kualitatif. Menurut (Moleong, 2012, p. 6), penelitian kualitatif adalah penelitian yang bermaksud untuk memahami fenomena tentang apa yang dialami oleh subjek penelitian misalnya perilaku, persepsi, motivasi, tindakan, dan lain-lain yang dilakukan secara holistik dan dengan cara deskripsi dalam bentuk kata-kata dan bahasa pada suatu konteks khusus yang alamiah dan dengan memanfaatkan berbagai metode ilmiah.

Bentuk penelitian ini adalah penelitian tindakan kelas (Classrooom Action Research). Penelitian ini merupakan penelitian terapan yang bertujuan ganda yaitu untuk memperbaiki situasi kerja dan untuk mengembangkan ilmu tindakan. Penelitian tindakan merupakan penelitian yang menggunakan berbagai pendekatan untuk memecahkan masalah praktis dalam pekerjaan. Penelitian tindakan terdiri atas dua kata yaitu 
penelitian dan tindakan dan hubungan keduanya. Hal ini mungkin sekali melakukan penelitian tanpa dilanjutkan dengan tindakan, dan pengujian tindakan tanpa penelitian. (Arikunto, 2014, p. 58) mengemukakan bahwa "penelitian tindakan kelas (PTK) adalah penelitian tindakan (action research) yang dilakukan dengan tujuan memperbaiki mutu praktik pembelajaran di kelasnya".

Penelitian ini akan dilakukan dalam dua siklus, siklus pertama dan siklus dua masing-masing dua kali pertemuan di setiap siklus terdapat beberapa tahapan yaitu: tahap perencanaan di mana peneliti menyiapkan perangkat pembelajaran, tahap pelaksanaan yaitu tahap memberikan materi pembelajaran melalui integrasi metode pembelajaran talking stick dan metode tebak kata, tahap pengamatan yang bertujuan untuk mengetahui keterlaksanaan kegiatan pembelajaran dan tahap refleksi yang bertujuan untuk mengamati hasil observasi dan mengetahui keberhasilan dan kekurangan sehingga kekurangan dapat di perbaiki pada siklus selanjutnya.

Instrumen pengumpul data yang di gunakan dalam penelitian ini adalah lembar observasi untuk melihat terlakasana atau tidaknya suatu proses pembelajaran di kelas, lembar wawancara, soal tes dan dokumentasi. Pengolahan data menggunanakan analisis deskriptif, yakni penyusunan data-data kemudian dijelaskan dan dianalisis serta dilakukan bersamaan dengan pengumpulan data. Menurut (Miles \& Huberman, 1992, p. 106) proses pengolahan data melalui tiga tahap, yaitu reduksi data, penyajian data ( display data) dan verifikasi data atau penarikan kesimpulan.

\section{HASIL DAN PEMBAHASAN}

Hasil tes siswa pada siklus 1 terdapat 14 siswa yang nilainya tuntas dan sembilan siswa yang belum tuntas atau yang tidak memenuhi kriteria ketuntasan minimal (KKM). Nilai yang diperoleh pada siklus 1 dengan nilai tertinggi 95 dan nilai terendah 40. Tes yang diadakan pada siklus 1 untuk melihat "Bagaimana Peningkatan Hasil Belajar Siswa Setelah Belajar Melalui Integrasi Metode Pembelajaran Talking Stick Dan Metode Pembelajaran Tebak Kata?". Soal tes berupa 10 butir soal essay yang dikerjakan siswa secara individu. Maka di peroleh nilai ratarata sebesar 72,22 dari 23 orang siswa. Ketuntasan belajar kalikal siklus 1 yaitu sebesar 60,87\% dalam kategori cukup, namun belum mencapai nilai klasikal yang ditentukan yaitu $85 \%$ dari jumlah siswa tuntas. Hal ini dapat diartikan bahwa hasil belajar belum maksimal.

Siklus 2 merupakan tindak lanjut dari siklus 1 yang bertujuan untuk memperbaiki hasil belajar siswa. nilai rata-rata sebesar 82,83 dari 23 siswa dengan jumlah siswa tuntas 21 dan siswa yang tidak tuntas 2 orang. Nilai terendah adalah 45 dan nilai tertinggi siswa adalah 100. Presentase ketuntasan klasikal pada siklus 2 yaitu $91,3 \%$ dan telah memenuhi persentase ketuntasan klasikal yang di tentukan. Setelah selesai memberikan tindakan dari setiap siklusnya melalui integrasi metode pembelajaran talking stick dan metode pembelajaran tebak kata yang disesuaikan dengan rencana pelaksanaan pembelajaran (RPP) oleh guru. Peningkatan hasil belajar siklus 1 dan siklus 2 dapat di lihat pada Tabel di bawah ini.

Tabel 1. Peningkatan hasil siklus 1 dan siklus 2

\begin{tabular}{cccc}
\hline Hasil penelitian & Siklus I & Siklus II & Peningkatan \\
\hline Nilai Tertinggi & 95 & 100 & $5 \%$ \\
Nilai terendah & 40 & 45 & $5 \%$ \\
Nilai rata-rata & 72,22 & 82,83 & $10,35 \%$ \\
Ketuntasan klasikal & $60,87 \%$ & $91,3 \%$ & $30,48 \%$ \\
\hline
\end{tabular}

Integrasi metode pembelajaran talking stick dan metode pembelajaran tebak kata merupakan suatu metode pembelajaran yang di gunakan sebagai alat bantu mempermudah dalam menjelaskan materi pembelajaran dan sangat cocok di terapkan. Menurut (Huda, 2014, p. 224) mengemukakan "Talking Stick merupakan metode pembelajaran kelompok dengan berbantuan tongkat, kelompok yang memegang tongkat terlebih dahulu wajib menjawab pertanyaan setelah mempelajari materi pokoknya".

Menurut (Suprijono, 2014, p. 109) penggunaan metode Talking Stick membuat peserta didik untuk berani berpendapat. Sedangkan metode tebak kata adalah adalah sebuah metode pembelajaran yang dalam pelaksanaannya menggunakan media kartu teka-teki yang berpasangan dengan kartu jawaban. Aturan permainannya sederhana siswa hanya menjodohkan kartu soal teka-teki dengan kartu jawaban yang tepat. 
Dengan menggunakan metode pembelajaran tebak kata ini, selain siswa menjadi tertarik dan menjadi berminat untuk belajar konsep belajar sambil bermain seperti ini juga memudahkan dalam menanamkan konsep pelajaran Ilmu Pengetahuan Sosial kepada siswa didik.

Berdasarkan hasil penelitian dari alat pengumpul data berupa lembar observasi aktivitas belajar siswa pada siklus 1 dan siklus 2 di kelas VIII SMP Negeri 4 Sepauk terlihat perubahan peningkatan pada sikap siswa dalam pembelajaran melalui integrasi metode pembelajaran talking stick dan tebak kata. Hasil observasi aktivitas guru pada siklus 1 adalah sebesar 65,50\%, sedangkan pada siklus 2 meningkat menjadi 91,99\%. Dan pada peningkatan hasil observasi aktivitas siswa pada siklus 1 adalah 70\%, sedangkan pada siklus 2 meningkat menjadi $95 \%$.

Berdasarkan analisis data hasil siswa diperoleh bahwa hasil belajar siswa mengalami peningkatan setelah melalui integrasi metode talking stick dan metode pembelajaran tebak kata pada mata pelajaran IPS Terpadu. Hasil belajar pada siklus 1 dengan nilai rata-rata 72,22\% dan meningkat di siklus 2 dengan nilai rata-rata sebesar $82,83 \%$. Sehingga terjadi peningkatan hasil belajar sebesar 10,61\%. Ketuntasan belajar klasikal siswa pada siklus 1 sebesar 60,86\% dengan 14 orang tuntas dan 9 orang tidak tuntas. Pada siklus 2 ketuntasan belajar klasikal mencapai 91,3\% dengan jumlah siswa yang tuntas 21 orang dan 2 orang tidak tuntas. Peningkatan ketuntasan klasikal siswa sebesar 30,43\%.

Hasil pengamatan pada hasil tes siswa pada pembelajaran melalui integrasi metode pembelajaran talking stick dan metode pembelajaran tebak kata tampak siswa mampu menunjukkan sikap perhatian, keaktifan dan kerjasama dalam kelas, sehingga siswa mampu memperoleh hasil belajar yang memuaskan.

Hasil penelitian ini sejalan dengan penelitian yang di lakukan oleh (Manurung, 2018) melakukan penelitian berjudul, Penerapan Metode Pembelajaran Talking Stick Dalam Upaya Meningkatkan Hasil Belajar Mata Pelajaran PKN Kelas VII-2 SMP Negeri 3 Kota Tebing Tinggi, hasil penelitian menunjukkan bahwa penggunaan metode talking stick dapat meningkatkan hasil belajar siswa yang dapat terlihat dari peningkatan ketuntasan belajar siswa, yaitu siklus 1 (80,56\%), siklus 2 (88,89\%), dengan ketuntasan klasikal sebesar 88,89\%. Sejalan dengan penelitian yang di lakukan oleh (Riyanto \& Ndapa Ate, 2016) penelitian yang berjudul "Peningkatan Hasil Belajar Biologi Pokok Bahasan Sistem Pencernaan Pada Manusia Melalui Penerapan Model Pembelajaran Tebak Kata Pada Siswa Kelas VIII SMP Kristen 1 YPK Malang”. Penerapan model pembelajaran tebak kata dapat meningkatkan hasil belajar biologi siswa kelas VIII SMP Kristen 1 YPK Malang pada pokok bahasan sistem pencernaan pada manusia. Peningkatan ini ditandai dengan meningkatnya ketuntasan belajar klasikal dari siklus ke siklus, di mana persentase jumlah siswa yang tuntas belajar pada siklus I hanya mencapai $66 \%$, selanjutnya pada siklus II meningkat menjadi $78 \%$ siswa tuntas belajar dan telah mencapai target ketuntasan belajar klasikal minimum.

Hasil penelitian terdahulu, menegaskan bahwa penggunaan metode pembelajaran talking stick yang di integrasikan dengan metode pembelajaran tebak kata dapat meningkatkan hasil belajar siswa pada mata pelajaran IPS pada tema pengaruh interaksi sosial terhadap kehidupan sosial dan Kebangsaan.

Hasil wawancara diperoleh bahwa siswa dalam mengikuti proses pembelajaran mudah memahami materi yang disampaikan, siswa merasa proses belajar mengajar menyenangkan, tidak membosankan, integrasi metode pembelajaran talking stick dan metode pembelajaran tebak kata membantu meningkat minat belajar siswa agar lebih aktif dan sangat menyenangkan sehingga dapat meningkatkan hasil belar siswa. Sedangkan hasil wawancara penelitian dengan guru mata pelajaran IPS diperoleh bahwa integrasi metode pembelajaran talking stick dan metode pembelajaran tebak kata sangat bermanfaat terhadap hasil belajar siswa. Hal ini terlihat bahwa siswa tertarik dan termotivasi dalam mengikuti proses belajar.

\section{KESIMPULAN}

Penggunaan integrasi metode pembelajaran talking stick dan metode pembelajaran tebak kata pada mata pelajaran IPS Terpadu di kelas VIII SMP Negeri 4 Sepauk dikategorikan sangat baik. Peningkatan hasil belajar siswa setelah melalui integrasi metode pembelajaran talking stick dan metode pembelajaran tebak kata pada mata pelajaran IPS Terpadu pada kelas VIII SMP Negeri 4 Sepauk adalah sebesar 30,43\%. Dari hasil siklus 1 dan siklus 2 nilai rata-rata meningkatkan 10,61\% dan ketuntasan klasikal meningkat 30,43\%. Dengan demikian dapat di simpulkan bahwa integrasi metode pembelajaran talking stick dan metode pembelajaran tebak kata dapat 
meningkatkan hasil belajar siswa di SMP Negeri 4 Sepauk pada Mata Pelajaran IPS tema pengaruh interaksi social terhadap kehidupan sosial dan kebangsaan.

Respon siswa terhadap pembelajaran melalui integrasi metode pembelajaran talking stick dan metode pembelajaran tebak kata pada mata pelajaran Ilmu Pengetahuan Sosial Terpadu di kelas VIII SMP Negeri 4 Sepauk menunjukkan respon yang baik. Hal tersebut terbukti dari hasil wawancara siswa dan guru yang berpendapat bahwa melalui integrasi metode pembelajaran talking stick dan metode pembelajaran tebak kata adalah sangat menyenangkan, menarik dan mudah dipahami sehingga membuat siswa termotivasi untuk belajar. Maka dapat disimpulkan bahwa respon siswa sangat baik dikarenakan melalui integrasi metode pembelajaran talking stick dan metode pembelajaran tebak kata dalam pembelajaran sangat menyenangkan sehingga membuat siswa senang dalam belajar.

\section{Daftar Pustaka}

Arikunto, S. (2014). Prosedur Penelitian Suatu Pendekatan Praktik. PT. Rineka Cipta.

Gagne, R. M. (1989). Kondisi Belajar dan Teori Pembelajaran. (terjemah Munandir). PAU Dirjen Dikti Depdikbud. Huda, M. (2014). Model-Model Pengajaran dan Pembelajaran. Pustaka Pelajar.

Kurniasih, I., \& Sani, B. (2016). Ragam Pengembangan Model Pembelajaran untuk Peningkatan Profesionalitas Guru. Kata Pena.

Manurung, H. (2018). Penerapan Metode Pembelajaran Talking Stick Dalam Upaya Meningkatkan Hasil Belajar Mata Pelajaran PKN Kelas VII-2 SMP Negeri 3 Kota Tebing Tinggi. School Education Jurnal PGSD FIP UNIMED, 8(1), 2013-2015.

Miles, B. M., \& Huberman, M. (1992). Analisis Data Kualitatif Buku Sumber Tentang Metode-metode Baru. UIP.

Moleong, L. J. (2012). Metodologi Penelitian Kualitatif. PT. Remaja Rosdakarya.

Putri, M. W., Rustini, N. K. P., \& Susrawan, I. N. A. (2016). Peningkatan Kemampuan Berbicara Dengan Menggunakan Metode Talking Stick Pada Siswa Kelas VIII 6 SMP Negeri 4 Denpasar Tahun Ajaran 2015/2016. Universitas Mahasaraswati Denpasar.

Riyanto, \& Ndapa Ate, Y. (2016). Peningkatan Hasil Belajar Biologi Pokok Bahasan Sistem Pencernaan Pada Manusia Melalui Penerapan Model Pembelajaran Tebak Kata Pada Siswa Kelas VII SMP Kristen 1 YPK Malang. 5(1), 8492.

Suprijono, A. (2014). Cooperative Learning Teori dan Aplikasi PAIKEM. Pustaka Pelajar.

Windari, Suniti, S. (2017). Penerapan Model Cooperative Learning Tipe Tebak Kata Dalam Meningkatkan Keaktifan Dan Hasil Belajar Siswa Pada Mata Pelajaran IPS Kelas VII B Di MTsN 1 Losari Kabupaten Cirebon. EDUEKSOS: Jurnal Pendidikan Sosial Dan Ekonomi, 6(1), 791-792. https://doi.org/10.2331/suisan.35.791 